\title{
新材料開発を支える先端計測拠点
}

\section{CFRP 層間㔈離計測のための \\ 中赤外レーザ超音波探傷システム開発* \\ Development of Mid-IR Laser Ultrasound Testing System for CFRP Delamination Measurement}

\section{小口かなえ ${ }^{* *}$ 榎 学** 畑野秀樹*** 草野正大 ${ }^{\dagger}$ \\ 山脇 寿 渡邊 誠}

Kanae OGUCHI, Manabu ENOKI, Hideki HATANO, Masahiro KUSANO, Hisashi YAMAWAKI and Makoto WATANABE

Key words CFRP, delamination, mid-IR laser, laser ultrasonic testing, computer simulation

\section{1.はじめに}

CFRP（炭素繊維強化プラスチック）の層間に生じる剥 離欠陥の非破壊検査試験として，レーザ超音波法（LUT） の活用が考えられている. LUTでは従来の超音波法の探 触子の代わりに，パルスレーザを試験体表面の微小領域に 照射することで超音波信号の送受信を行うため，完全非接 触探傷が可能であり, 複雑形状部材を多く含む航空機や自 動車の機体などへの適用が期待されている.CFRPに対す るLUTでは，従来用いられているYAGレーザや $\mathrm{CO}_{2} レ$ ーザの波長带域が CFRP の超音波発生に最適化されてお らず，超音波強度が低く $\mathrm{SN}$ 比が劣るという問題点があっ た。また，これまでの研究でCFRP のマトリクスである エポキシ樹脂の吸収帯域である $3.2 \mu \mathrm{m}$ 近傍の中赤外光が, CFRP 内への超音波発生に適し， かつ非破壊的であること が分かっているが，LUT 光源として十分な実用性を備え た $3.2 \mu \mathrm{m}$ 近傍の光源はこれまでに開発されていない. 本 グループでは, 光パラメトリック発振法 (OPO) で, 周 期分極反転 Mg:SLT を用いた波長变換素子により，LUT に適した中赤外レーザ光源の開発に成功している ${ }^{1)}$. 本稿 では, 中赤外レーザ超音波探傷システム, 剥離計測時の影 響要因, コンピュータ・シミュレーションによる CFRP でのレーザ超音波伝播解析等について述べる。

\section{2. レーザ超音波探傷システム}

図 1 にLUT システム（プロトタイプ）を示す。レーザ は基本波レーザ一体型のコンパクトな筐体で，可搬性を有 している。 OPO 波長変換部では，50 mJ の基本波レーザ

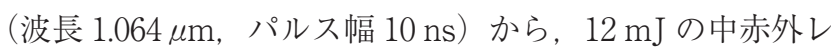
ーザ（波長〜3.2 $\mu \mathrm{m}$ ）を取り出せる. システムは中赤外レ

*原稿受付 令和元年 12 月 10 日

*東京大学（東京都文京区本郷 7-3-1）

***無所属

物質・材料研究機構（茨城県つくば市千現 1-2-1）
ーザ光源, サンプル設置用 $X Y$ ステージ, レーザ干渉速 度計で構成される。光学スイッチの切り替えにより, YAG 基本波光, 中赤外光を超音波光源として使用でき る. 光源からパルスレーザがサンプルに照射されると, 照 射領域では光エネルギー吸収にともなう熱ひずみにより超 音波が発生する。サンプルを伝播した超音波の受信は, 受 信用レーザと干渉速度計により行う，XYステージの移動 により検査領域全体に走査させることで, A-Scan, BScan, C-Scan データを取得することができる122).

LUT システムによる超音波透過法での剥離欠陥の計測 例として図 2 に厚さ $2 \mathrm{~mm}$, 直交配向 CFRP (8 層積層) に1，2，5，10 mm 角の正方形の疑似剝離欠陥を含むサン プルの C-scan 画像を示す. 図の中心付近の色の濃い部分 が久陷部分であり, 超音波透過法の測定では, $1 \mathrm{~mm}$ 角程 度の大きさの剥離欠陥まで検出可能である。

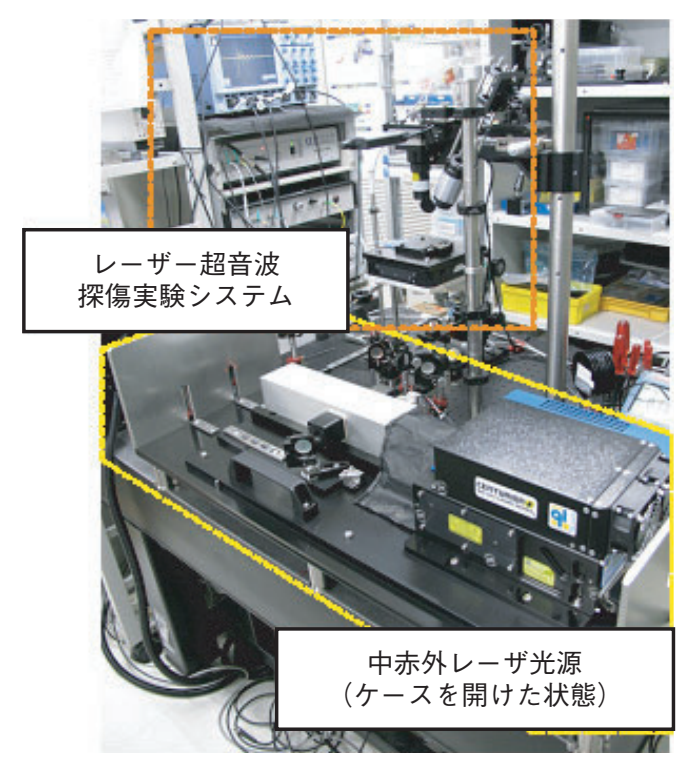

図 1 LUT システム (プロトタイプ) 

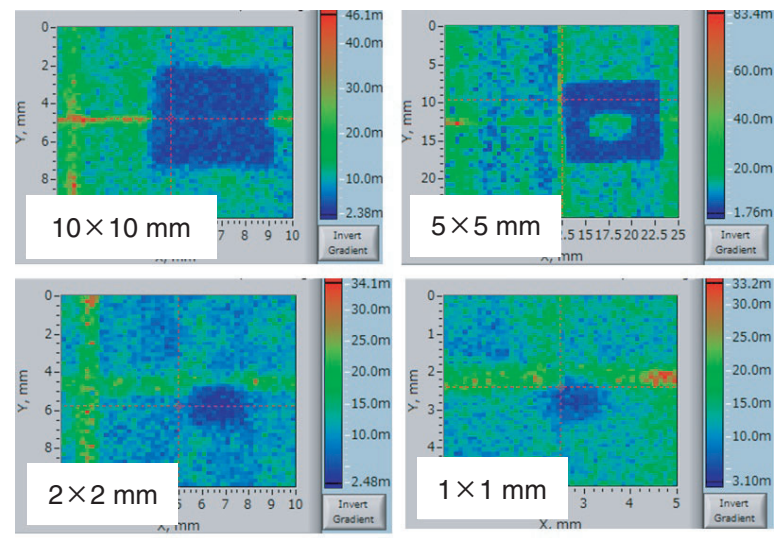

図 2 正方形疑似欠陥剝離欠陥を含む $2 \mathrm{~mm}$ 厚さ CFRP 直交配向材 （8 層積層）での剝離計測 C-scan 画像，中心付近の色の濃い 部分が欠陥を表す

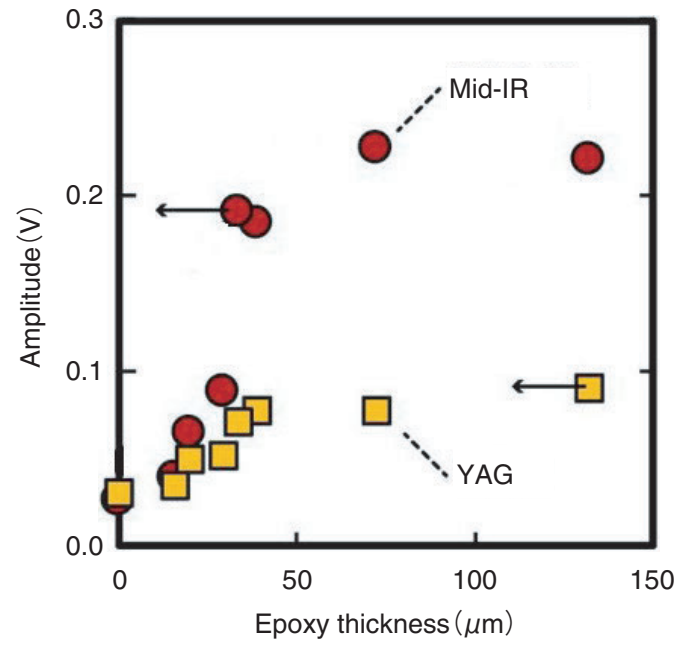

図 3 エポキシ樹脂コーティングサンプルでのエポキシ樹脂厚さと, サンプル裏面での垂直方向超音波速度波形振幅の関係

\section{3. 剝離計測時の影響要因}

これまでの研究で, 試験体表面樹脂量が中赤外レーザ照 射による超音波発生に大きな影響を与えることが明らかに なっている ${ }^{1)}$ 。そこで CFRP 表面樹脂厚さの超音波への影

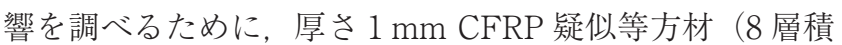
層）およびエポキシ樹脂コーティング（樹脂厚さ 0 〜 130 $\mu \mathrm{m})$ を施した同サンプルを準備した。さらに、レーザ特 性による，超音波発生への影響を明らかにするために，レ ーザエネルギー密度をおよそ $0.05 \mathrm{~J} / \mathrm{cm}^{2}$ とした条件で, 光源を中赤外レーザ，YAGレーザと切り替え，それぞれ のサンプルに対し実験を行い，発生した超音波の比較を行 つた ${ }^{3)}$. 図 3 に, サンプル裏面で検出した, 垂直方向超音 波速度波形の振幅を，樹脂厚さごとにプロットしたグラフ を示す。いずれのサンプルでも中赤外レーザでは，YAG レーザと比較して，超音波振幅が数倍程度大きくなり，コ ーティングサンプルでは, コーティングなしサンプルと比
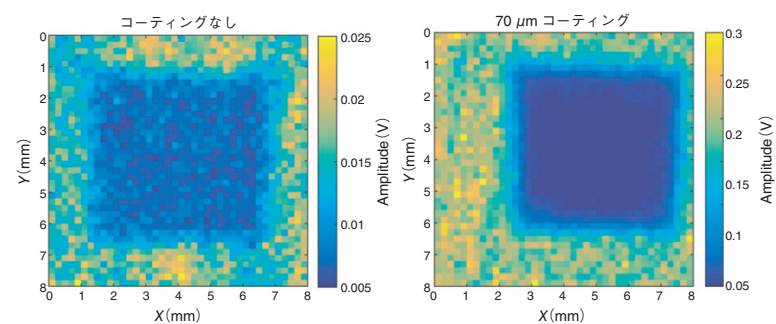

図 $45 \mathrm{~mm}$ 角疑似欠陥を含む $2 \mathrm{~mm}$ 厚さ CFRP 疑似等方材 (8 層積 層), $70 \mu \mathrm{m}$ 樹脂コーティングサンプル，での剝離計測 C-scan 画像、コーティングサンプルでは SN 比の向上を確認

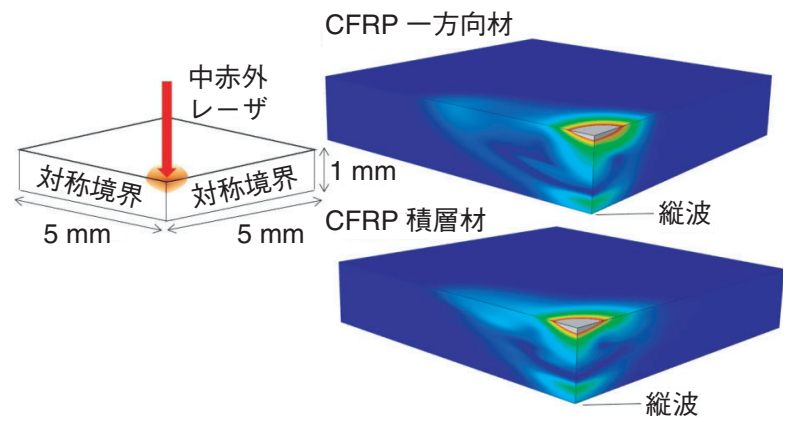

図 $51 \mathrm{~mm}$ 厚さ CFRP 一方向材, 直交配向材 (8 層積層), での超 音波伝播シミュレーション結果, 中赤外レーザ照射後 $0.5 \mu \mathrm{s}$ の超音波変位分布, 超音波探傷に有効な振幅の大きい縦波の 励起を確認

較して，振幅が最大で 6 倍ほどに増大寸ることが分かっ た。また，樹脂厚さおよそ $50 \mu \mathrm{m}$ までは樹脂の厚さにと もない超音波振幅の増大が見られ，50 $\mu \mathrm{m}$ 以上では振幅值 に大きな変化が見られなかった。これらの結果から，50 $\mu \mathrm{m}$ 程度コーティング樹脂層により超音波振幅が最も効率 的に増大することが明らかになった。 図 4 に $5 \mathrm{~mm}$ 角の 疑似剝離欠陥を含む $2 \mathrm{~mm}$ 厚さ $\mathrm{CFRP}$ 疑似等方材（8 層積 層）㧍よび $70 \mu \mathrm{m}$ 樹脂コーティングサンプルでの欠陥部 分の C-scan 画像を示す. $70 \mu \mathrm{m}$ 厚さコーティングサンプ ルでは明らかな SN 比の向上が確認された。

\section{4. 超音波探傷シミュレーション}

CFRP での中赤外レーザ超音波伝搬シミュレーションの 結果を示す。沉用コードABAQUS を用いた有限要素法に より超音波伝播解析モデルを開発した。図 5 に厚さ $1 \mathrm{~mm}$ CFRP 平板に対するLUT のシミュレーションモデルを示 す。レーザ超音波伝播を解析するために，板表面から深さ 方向にレーザ光を照射した際の光吸収による加熱領域を設 定し，加熱領域では，Bouguer-Lambert-Beer 則による， 入射光の板表面からの光侵透深さと光の強度の関係式によ る温度分布を仮定した。 CFRP 積層材は直交配向 CFRP （8 層積層）とした，各層の物性值として，配向方向に応 じて回転の座標変換をした CFRP 一方向材の物性值を用 いている。 入射レーザ光は正弦波半波のパルスとし，レー ザ時間幅, スポット径, パルスエネルギー密度はそれぞ 
れ，10 ns，1 mm，10 mJ とした。図 5 にレーザ照射後 0.5 $\mu \mathrm{s}$ の, CFRP 一方向材, 積層材での超音波変位分布を示 す。エポキシ樹脂や CFRP の表面に中赤外レーザを照射 すると，照射面から深さ $400 \mu \mathrm{m}$ 程度の領域が光エネルギ 一の吸収により加熱される。シミュレーションでは加熱領 域での垂直方向の熱ひずみにより振幅の大きい縦波が発生 し，裏面に到達する様子が明らかになった，CFRP一方向 材は, 繊維方向（水平方向）の音速が繊維と垂直な方向と 比べて 3 倍ほどであるため，水平方向と垂直方向での波面 の到達位置に大きな違いが見られる。また，積層材では， 層間での超音波の反射や音響異方性の影響などにより変位 分布は複雑なものとなることが分かった。

\section{5. を と め}

中赤外レーザ光源は，従来光源と比較して，CFRPに $\mathrm{SN}$ 比の高い縦波超音波を発生させることが可能であり, この光源を超音波発生源としたLUTシステムでは, CFRP 積層板に含まれるサイズ $1 \mathrm{~mm}$ 角までの層間剝離の 計測に成功している。また，表面にエポキシ樹脂コーティ ングを施したサンプルでの計測では，明らかな SN 比の向 上が見られ，本システムの FRP 製機器・構造物の表面卜 ップコートおよびウレタンコーティングへの活用の可能性 が示された。ささらに本システムでは，CFRP-合金との不 完全接合部等の検出も可能となっており ${ }^{1)}, \mathrm{CFRP}$ 製製品 全般の非破壊検査への活用が期待される.

\section{謝辞}

本稿は内閣府の戦略的イノベーション創造プログラム （SIP）による研究成果に基づく，関係者各位に深くお礼 申し上げる

\section{参 考 文 献}

1) H. Hatano, M. Watanabe, K. Kitamura, M. Naito, H. Yamawaki and R. Slater: Mid IR pulsed light source for laser ultrasonic testing of carbon-fiber-reinforced plastic, J. Opt., 17 (2015) 094011.

2) H. Hatano, R. Slater, S. Takekawa, M. Kusano and M. Watanabe Optimization of mid-IR generation from a periodically poled $\mathrm{MgO}$ doped stoichiometric lithium tantalate optical parametric oscillator with intracavity difference frequency mixing, Jpn. J. Appl. Phys., 56 (2017) 072701.

3) M. Kusano, H. Hatano, M. Watanabe, S. Takekawa, H. Yamawaki, K. Oguchi and M. Enoki : Mid-infrared pulsed laser ultrasonic testing for carbon fiber reinforced plastics, Ultrasonics, 84 (2018) 310.

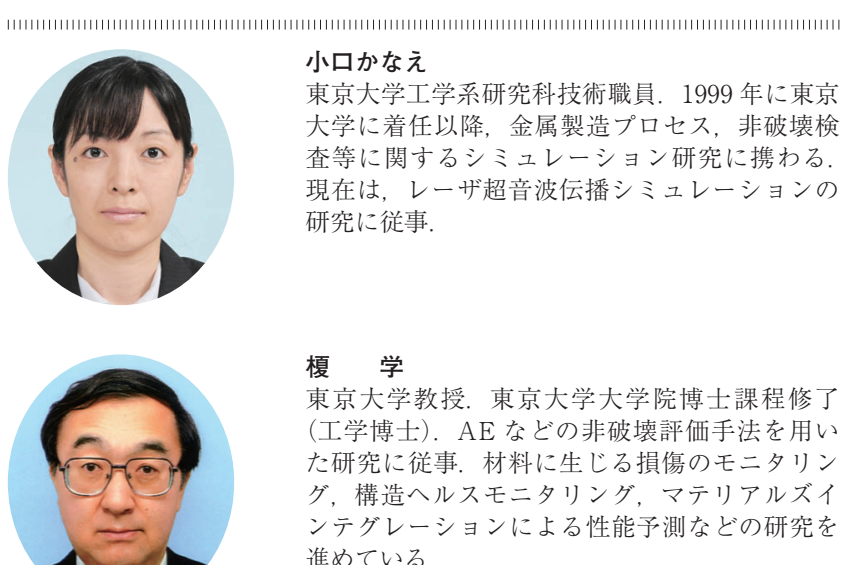
進めている.

\section{畑野秀樹}

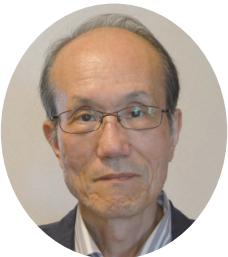

東北大学大学院工学研究科修了, 工学博士. 物 質・材料研究機構に扔いて, 非線形光学連よび PP-Mg:SLT を用いた光波長変換とそのレーザ 応用に関する研究等に従事. 2017 年退職. SIP プロジェクトでは, レーザ超音波探傷のための 中赤外レーザシステム開発を担当。

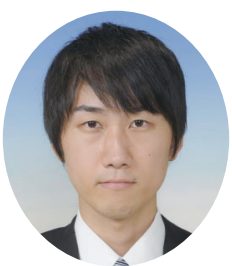

\section{草野正大}

物質・材料研究機構 構造材料研究拠点積層又又 ート材料グループ研究員，2016 年 3 月に東京工 業大学大学院理工学研究科化学工学専攻博士課 程を修了後, 物質 - 材料研究機構に着任. レー ザ超音波の研究開発に携わるかたわら，積層造 形の研究にも従事.

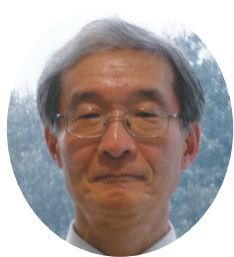

\section{山脇 寿}

物質・材料研究機構 構造材料研究拠点接合・造 型分野積層スマート材料グループ任期制研究員 1980 年, 科学技術庁金属材料技術研究所（現在 の物質・材料研究機構）に入所，以来，超音波 探傷, レーザ超音波, 超音波の計算機シミュレ ーション等の研究に従事。

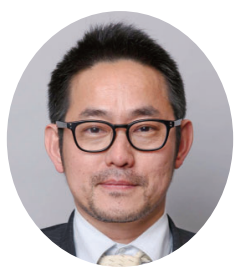

渡邊 誠

物質. 材料研究機構 構造材料研究拠点接合. 造 型分野分野長. 2004 年に物質・材料研究機構に 着任以降、コーティング材料を中心に非破壊評 価技術の研究に従事して抢り，近年はさらにマ テリアルズインテグレーション技術開発に取り 組んでいる. 